\title{
Local Cadre Elites and Policy Implementation in Contemporary China
}

\author{
Anna L. Ahlers and Gunter Schubert
}

\begin{abstract}
'The relations between any bureaucracy and the other centres of political power in a society pose a basic dilemma of how to establish effective control over the bureaucracy and at the same time not to restrict its autonomy to the point of making it impotent, formalistic and inefficient' (Eisenstadt 1958, p. 103).
\end{abstract}

\section{Introduction: Conceptualizing County and Township Cadres as a Political Elite}

From the earliest times of the mandarin bureaucracy to the contemporary post-soviet-styled cadre apparatus, the relationship between political authority and administrative efficiency has been a topic of considerable importance and complexity in China. Throughout history, imperial China's stability did not foremost rely on coercion and control of local administrators but on the emperor's capacity to secure the loyalty of local mandarins to implement state policies. In an empire as vast as the Chinese, this strategy to reign could only work with granting local officials enough autonomy 'to take measures according to local conditions' (yindi zhiyi), that is, to adjust upper level directives in a way that they could work locally. The need to grant authority and autonomy to decision-making local officials while at the same time keeping them under control and loyal to the emperor were probably the most tricky tasks of imperial governance (Chü 1962; Wang 2008; Schoppa 2010; Barbieri-Low 2011), and dynastic change was always related to political failure in this regard. Needless to say, the local gentry and the mandarins constituted a most influential and powerful elite in this system. Although many features of imperial administration were maintained after the fall 
of the Qing dynasty (the hierarchical structure of subnational levels, the system of frequently rotating leading officials, much bureaucratic terminology) some things, of course, changed, most notably the structure and scope of bureaucratic power. The Chinese Communist Party (CCP) was subjected to the logic of a Leninist party system which produced, inevitably as it seemed, much of that power. As a matter of fact, communist parties all over the world have become famous for their vast and ever-growing bureaucracies, and for the continuous struggle to control them: ${ }^{1}$

They [high level bureaucratic officials], have played especially important roles in societies such as the Soviet and Chinese Communist regimes whose theoretical goal was to eliminate them. Indeed as late as the 1960s Mao Zedong's cultural revolution was designed to abolish or at least sharply reduce bureaucratic power. Mao had a point. Bureaucrats were blunting the cutting radical edge of the Chinese revolution for, as Weber argued, bureaucrats tend to routinise decision making. Mao did not succeed, for Weber was also correct in asserting, when many social theorists thought otherwise, that socialism could only increase the size and power of bureaucracy. (Rothman 2011, p. 11659)

In the absence of autonomous mechanisms of control (especially judicial or public oversight), there is a constant fear among Chinese leaders that administrative apparatuses, especially at local level, accumulate too much power by controlling scarce resources and steering the implementation of central state policies. At the same time, the Chinese leadership had always to be aware that developmental success and the overall stability of the political system depended on local officials' vigor, competence and effectiveness, a fact not only proven during the early stages of the Party's revolutionary and experimental bases (Heilmann 2008, 2011), but most clearly after the 'reform and opening' policies had been launched in the early 1980s and the ensuing decentralisation and delegation of central state authority to the local

\footnotetext{
${ }^{1}$ The ambivalent attitude of 'socialist and communist camps' towards the bureaucracy was always fuelled by the 'realisation of its importance as a means of implementing social goals and reform' (...) and the simultaneous 'suspicion of it as a tool in the hands of the capitalist ruling classes' (Eisenstadt 1958, p. 101).
} 
state (Wedeman 2003). Local officials, therefore, have been critical for CCP regime survival from the very beginning of the Party's reign and have remained so ever since.

Max Weber, in general, regarded leading bureaucrats as 'key political elites' (cited in Rothman 2011, p. 11659). ${ }^{2}$ Furthermore, he coined the term 'Berufspolitiker', 'a 'politician with a sense of vocation" who combines a passionate conviction in supra-mundane ideals that politics has to serve and a sober rational calculation of its realisability in this mundane world' (Kim 2012: n.a.). Sometimes, such a viewpoint also entails that (local) officials' elite status is seen as coming with moral obligations (Houlgate \& Baur 2011). For the case of contemporary China, and very much in line with the theoretical framework and empirical focus of this volume, Heberer and Schubert (2012) conceptualized county and township cadres in their respective jurisdictions as 'strategic groups' and grounded their analytical approach on key concepts of Bourdieuan theory. Local officials hold deeply entrenched collective dispositions, i.e., a specific habitus ${ }^{3}$ dispose of different forms of capital $^{4}$ and strive for safeguarding and strengthening their relative autonomy ${ }^{5}$ and power position in the field of local politics (local administration). Their shared capital and habitus, i.e., their

\footnotetext{
${ }^{2}$ Scholars of the history of Prussia, another example of a long-living authoritarian bureaucratic tradition, have shown that the local bureaucracy in Prussia's vast rural stretches was the driving force of the famous reforms in the late $18^{\text {th }}$ and early $19^{\text {th }}$ century, assigning them a status of 'social class' to highlight their expertise, self-assuredness and competence (Koselleck 1967). For a comparison of Western/Weberian and contemporary 'Chinese' public administration models, see Ang (2016).

${ }^{3}$ Habitus refers to similar life-style patterns and value orientations of local cadres which result from their privileged social status in the field of local politics or administration. This habitus distinguishes them from other actors competing with local officials for political power and field-related benefits, for instance private entrepreneurs, SOE managers or social activists. In this chapter, we do not discuss those other elites.

${ }^{4}$ For local cadres' different forms of capital see Heberer and Schubert (2012, p. 237). Besides economic capital (above-average income), cultural capital (higher education and professional knowledge), social capital (extensive guanxi-networks) and symbolic capital (in terms of reputation, prestige, privileges and status) the authors added structural capital as an additional form, referring to local cadres' special knowledge of laws, political regulations and bureaucratic procedures inaccessible to others being outside the Party system (tizhi wai) - but inside the field of local politics.

5 'Relative autonomy' in this chapter refers to local cadres' political space to formulate (adjust) and implement upper level policies in a way that allows them to prove that they are up to their jobs, or to protect themselves from sanctions in case of implementation failure.
} 
'positional closeness ${ }^{6}$ in China's administrative and social hierarchy, and their goal-oriented behavior makes leading county and township cadres a 'strategic group' or, a political elite in the terminology of this volume. As such, they pursue coordinated strategies to ensure smooth and effective implementation of policies and policy guidelines passed down from superior administrative levels, a prerequisite for leading local officials to secure career advancement via promotion. This comprises strategies to enforce compliance throughout the local bureaucracy, not only for the sake of sound policy implementation but also in order to respond uniformly to upper level pressure by suitable counter-policies (duice).

In focusing on leading county and township cadres as local political elites, ${ }^{7}$ this chapter highlights how these elites shape and steer governance in China's vast rural areas where local officials act as both agents of the central state and lower-level principals, who enjoy considerable autonomy and power (in terms of policy formulation and implementation on the ground), but also are subject to a number of institutional and policy constraints determined by the central state. ${ }^{8}$ In today's local state, county and township cadres are not only responsible for the adjustment of upper level policy guidelines to make them fit local conditions; they

\footnotetext{
${ }^{6}$ Social status and shared capital result from 'positional closeness' in a social field and arguably create a class of local officials which exists in contemporary China.

${ }^{7}$ We take for granted that leading county and township cadres as a political elite should be investigated separately from authority roles at higher (prefectural/provincial) and lower (village) levels. County and township cadres are the 'executive branch' of local government, setting them apart from the province and the prefecture/municipality more concerned with the formulation of guidelines, and from the villages which have no autonomy in terms of policy implementation whatsoever though they may ally and cooperate closely with their superiors in managing village finance or attracting private capital (Chen 2014).

${ }^{8}$ It is a characteristic of the Chinese policy process that enormous discretion is given to local cadres to adjust upper level policy programs and guidelines. As Christian Göbel stated, 'only abstract achievement standards are formulated (often called 'unified national policy' or tongyi zhengce), but no guidelines on how to achieve them (called 'dispersed policymaking' or fensan juece). This method is the result of a paradox that has characterized central-local relations since reform and opening, and even before. On the one hand, to prevent the localities from distorting central policies or not implementing them at all, the application of 'hierarchical' instruments or regulation, supervision, and punishment is deemed necessary. On the other hand, however, policies cannot be implemented uniformly in China's almost 50,000 vastly different township-level entities if dysfunctional effects are to be avoided. Hence, the localities must be counted upon to work out the implementation details' (Göbel 2011, p. 164).
} 
must also be innovative and proactive in their responses to 'policy stimuli' from above and develop them further. In a kind of laboratory process they are called upon to set up pilot programs ahead of their national adoption (e.g. in the context of land use rights reform or the incorporation of villages in rural towns) or find local best practices by experimentation to feed into central government policy formulation (e.g., in agricultural specialisation, the expansion of public service facilities or the setting up of new forms of urban administration) (see Heilmann 2009; Ahlers \& Schubert 2013). In that sense, they are major enforcers and enablers, and their success and failure in local policy implementation are critical for the overall resilience and stability of the Chinese political system.

The chapter shows how structural constraints impacting on the field of local politics have been managed by county and township cadres to ensure adjusted, innovative and effective policy implementation (for a definition of effective policy implementation, see below). Our approach analyzes local political elites' agency in policy implementation processes, and how local cadres learn and constantly adapt to secure their position as loyal central state agents and effective local state principles. The approach differs from many other studies which investigate local cadres' political behavior, using terms like collusion, patronage, rentseeking, etc. (Cai 2004; Eaton \& Kostka 2014; Hillman 2010; Kostka 2012; Smith 2009, 2010, 2013; Zhou 2010; Zhou, Ai \& Lian 2012), or looking at their educational background, recruitment, and training (Burns 2006; Burns \& Wang 2010; Landry 2008; Li \& Bachman 1989; Lollar \& Hamilton 2010; Seckington 2007; Wang \& Pavlicevic 2014). Our fieldwork across the country confirms that local cadres in present-day China must legitimise themselves vis-à-vis the central state, their immediate superiors and the local population by 'delivering results' in their respective jurisdictions; and in doing so, they not only strengthen local political authority but help the central state to maintain its legitimacy, too. We support our 
argument by summarizing empirical findings from several rounds of qualitative field research in different Chinese provinces conducted since 2008, partly related to a project that investigated local approaches to the 'Building a New Socialist Countryside' (Xinnongcun jianshe/BNSC) policy program officially launched in 2006 (Ahlers \& Schubert 2009, 2013; Schubert \& Ahlers 2012a; Ahlers 2014b). ${ }^{9}$

\section{County and Township Cadres in Local Administration: Institutional and Policy}

\section{Constraints}

Local level party and government cadres in the People's Republic of China have always been expected to internalise the vanguard role of the CCP regime in driving forward societal, political and economic change. ${ }^{10}$ Over the decades of 'reform and opening' since the late 1970s, however, while much of the policy process was delegated to local officials (Wedeman 2003), their ensuing autonomy and power in many places became overtly dysfunctional: Land expropriation and the imposition of illegal taxes and fees were the most notable issues of local discontent and deteriorating cadre-peasant relations throughout the 1990s and 2000s. ${ }^{11}$ The central leadership fueled this conflict-laden relationship by making local cadres responsible for policy failures in the decades of decentralisation after 'reform and opening' (Göbel 2010, 2011, 2012). They were an easy scapegoat for state propaganda and the media which was tolerated to cover local governments' misconduct extensively, veiling the fact that

\footnotetext{
${ }^{9} \mathrm{We}$ will not delve into the details of this macro policy here, but rather refer to it for pointing at a number of observations supporting the argument that county and township cadres shall be understood as local elites. Fieldwork on local officials' autonomy and strategies to implement policies was conducted by the authors in different counties of Jilin, Shaanxi, Zhejiang, Jiangxi, Jiangsu, Fujian and Guangdong provinces between 2008 and 2014.

${ }^{10}$ For a meticulous description of local level cadres' position and function in the Chinese political system, see Zhong 2003, chap. 4.

${ }^{11}$ As has been argued by many scholars, it was foremost due to unfunded mandates from above, not corruption, that induced local cadres to divert funds and drain money from the populace for financing the implementation of 'political achievement projects' (zhengji gongcheng) or basic public goods provision (Zhong 2003, pp. 143-145).
} 
much the mess in the countryside was related to the lack of public funding from above.

However, facing increasing numbers of petitions and outbreaks of local protests, the central leadership found it soon necessary to step in with a number of substantial governance reforms.

In 1998 it formalized direct village elections, introduced in 1987 on an experimental basis, and made them obligatory nation-wide to make grassroots cadres more accountable (Schubert \& Ahlers 2012b). However, village governments are strictly controlled by their non-elected superiors so that much depends on the latter's political behavior. Since 1993, the government has taken a number of steps to reform China's civil service system in order to build up a professional and effective cadre apparatus (Burns 2007; Burns \& Wang 2010; Jing 2010; Yu 2016), which can be seen as a complementary measure of 'grassroots democracy'. Assessing civil service and administrative reforms since then, Wang and Pavlicevic acknowledged that

(...) while political reliability and commitments still feature prominently when the Party staffs the state and party bodies, rapid economic development and social changes have amplified the need for capable and competent managers and administrators, in order to deliver successful governance. Whereas in the past political loyalty played a crucial role for officials' success within the state ranks, today professional competence has become more central. (...) As such, the ability to perform in practical terms will gradually outstrip ideo-political commitments in importance. For that reason, we conclude that China's Party-state meritocracy is in a state of transition (2014: loc. 1895). ${ }^{12}$

Most importantly, the central state initiated a new official discourse starting in the early $\mathrm{Hu}-$ Wen era (Ahlers 2014a, 2014b) by introducing the formula of 'Building a Service-oriented Government' (jianshe fuwuxing zhengfu), pinpointing a comprehensive approach to enhance

\footnotetext{
${ }^{12}$ However, cadre evaluation systems still run a number of indicators directly concerned with cadre 'morality' (Heberer \& Trappel 2013) which figures prominently in party terminology and has even gained in importance since the new leadership of Xi Jinping and Li Keqiang took office.
} 
administrative efficiency and improve the reputation of local officials. ${ }^{13}$ This approach is foremost concerned with improving the provision of public goods and services. Wu Wei et al. characterise it as follows:

A service-oriented government represents a governance mode that places service in the center of government functions, which requires a fundamental transformation of government functions in Chinese public administration. The service-oriented government asks for a sufficient understanding of the needs of citizens and business that is critical to meet the goals of creating a favorable socioeconomic environment and providing quality public services (2013, p. 2).

As with many policy measures initiated by the central government, this was spelled out in very abstract terms, but since the accompanying propaganda offensive was so pervasive and the concept also written into many policy papers and evaluation guidelines passed down from upper levels, local governments reacted swiftly. For instance, 'administrative supermarkets' (xingzheng chaoshi) have been set up at almost all administrative levels nation-wide, including rural areas. Following the line of 'one-stop shops', ${ }^{14}$ these centers - called 'stations' (fuwu zhan) in townships and villages - now pool services for farmers, private entrepreneurs, and ordinary residents, such as information about and application for subsidies, certificates, and social security schemes. They often provide conflict mediation as well. The rationale here is to create cross-sectional responsibilities which help to tighten bureaucratic structures, ensure administrative transparency, and facilitate contact-making with local officials and administrative personnel.

\footnotetext{
${ }^{13}$ At almost the same time the slogan 'build administration according to the law' (yifa xingzheng) was resurrected. Both slogans were later integrated into the 'Building a Harmonious Society' concept (Wei 2006) and further promoted by the Party propaganda (CCP News 2007; CCP Central Committee 2010; 2011).

${ }^{14}$ As part of 'New Public Management' approaches, this innovation originated in the United Kingdom and then spread through the local administrations of the European Union. 'One-top shops' are also used in Australia and the US. The main idea behind them is to enhance efficiency and convenience by providing 'service seekers' - particularly in the realm of social security, employment services, and business registration - with a place where relevant administrative responsibilities and procedures are pooled (Mulgan 2002; Ongaro 2004; Wiggan 2007). Since it was not opportune for China to directly adopt the Western term, 'supermarket' is often used colloquially instead. We are grateful to $\mathrm{Yu}$ Keping to point this out to us; see also Ahlers 2014b.
} 
'Service-oriented government' figured prominently in the BNSC policy program and is by now part and parcel of any national policy initiative or guideline targeting local governance reform (Xinhua Press 2006; Ahlers 2014b). Today, local Party and government cadres are continuously advised to become 'service providers' and 'explorers' in, for example, developing urbanisation strategies (zhongguo tese xinxing chengzhenhua) (Ahlers 2015; Xinhuanet 2014), building up and expanding social welfare security systems (Stepan \& Müller 2012), and - generally speaking - implementing the CCP's November 2013 reform agenda at the local level. Most notably, they should foster cooperation with the private sector and push local banking reform in order to facilitate access to credit for cash-starving private enterprises. But not only are local governments summoned to treat citizens more like clients, they are also encouraged streamline their administrative apparatuses by contracting out a growing number of public services to the private sector (CCP Central Committee 2013).

Besides the new focus on 'service-oriented government' shaping the field of local administration for China's county and township officials, there were more reforms which impacted significantly on their political manoeuvring space. The nation-wide implementation of a 'Rural Tax-For-Fee (RTF) Reform' (nongcun shuifei gaige) between 2000 and 2003 abolished local governments' notorious practice of charging excessive fees for all kinds of (real or imagined) services. Although the immediate benefits of this measure for the peasant population are contested among scholars (Bernstein \& Lü 2000, 2003; Göbel 2008a, 2008b), there is no doubt that it cut deeply into the budgetary income of local governments and thus posed a serious challenge for county and township officials to fulfil their tasks. The RTF reform was soon complemented by scrapping the agricultural tax in 2006 , thus eradicating the 'peasant burden' which had so much troubled cadre-peasant relations in the decades before 
(Kennedy 2007; Göbel 2010). ${ }^{15}$ At the same time, their policy mandates and expenditure obligations remained the same. This exacerbated the budgetary problems of local governments which had long been chronically underfunded (Liu \& Tao 2007; Guo 2008; Sato 2008; Wong \& Bird 2008; Yep 2008). Although the central government had introduced an intergovernmental transfer system in 1994, which was gradually expanded to better accommodate the financial needs of China's less developed areas after the beginning of the Hu-Wen administration, the impact of the mentioned fiscal reforms was not sufficiently cushioned. Local governments remained under serious 'financial stress', complicating their obligation to make good on the central government's promise to 'equity-enhancing politics' (Liu 2012; Huang \& Chen 2012; Guo 2010; Shah \& Shen 2008; Tsui \& Wang 2004). Only after the mid-2000s did the central government start to compensate local governments for their losses in revenue better by substantial subsidies sent through the intergovernmental transfer system and by allocating earmarked funds for major policy mandates, such as agricultural specialisation, rural urbanisation and infrastructural development (Ahlers 2014b; Göbel 2010; Lou \& Wang 2008; Su 2009; Li 2007). ${ }^{16}$ This new inflow of money, however, came with a heightened complexity of policy project line applications for county and township governments. Simultaneously, sound monitoring of the eventual allocation of these funds and county and township budget management was made an indicator in the annual performance evaluation of leading cadres and government bureaus (Ahlers 2014b).

\footnotetext{
${ }^{15}$ It was calculated that the financial burden of peasants amounted to as much as 20-30 percent of their annual income (Tao et al. 2011). The abolition of the agricultural tax actually marked a paradigm shift, meaning that, from this moment on, 'central and local finance began to cover rural public goods and services, with the state thus replacing the farmers as the main provider of these services' (Ye 2009, p. 140).

${ }^{16}$ According to the CCP Central Committee's reform agenda promulgated in November 2013, the division of tax categories for central, shared and local taxes should be revised. Second, an increase in general transfer payments (yibanxing zhuanyi zhifu) should bolster local finances, while, at the same time, earmarked project-funding (zhuangxiang zhuanyi zhifu) should be reduced by one-third and gradually abolished. It was further planned to cut, and eventually abolish, local matching fund requirements (CCP Central Committee 2013).
} 
Performance evaluation (kaohe, kaoping) itself became stricter, too. While this institution is a powerful tool of the central state to supervise and govern local state party elites, it has long been described by scholars as setting the wrong incentives, namely, to induce local cadres to focus on measurable policies only (instead of taking care of quality), fabricate numbers and investing in fancy image-building projects without much value in terms of public goods provision. In other words, the performance evaluation system has been regarded as encouraging selective policy implementation and goal displacement to the detriment of satisfying public needs (O’Brien \& Li 1999; Cai 2004; Whiting 2004). However, over the last decade, evaluation procedures have become more sophisticated. New policy priorities have been integrated into the system, making it more a performance-regulating and goalcommunicating tool than an instrument of cadre management control. While major policies, such as economic growth and birth control, have retained their 'one veto item' (yipao foujue $)^{17}$ status, there has been a shift from 'GDP-focused' (GDP xing) indicators of 'extensive growth' to the incorporation of 'qualitative development', i.e., indicators measuring achievements related to 'green GDP' and UN-defined human development. Public opinion has been factored in to some extent as well (CCP Organisation Department 1998; Zhuang 2007; Cui 2009; Heberer \& Senz 2011). Most importantly, 'social stability' (shehui wending) has been included as a 'one veto item' in each and any evaluation guideline. That means any occurrence of social unrest, even legal petitions submitted to whatever government level, will seriously affect the performance record of an official or a government bureau. The 'social stability imperative' has severely constrained the behavior of local bureaucracies. While until recently protests were often crushed by violent means, county and township cadres are now more cautious and try to anticipate and avoid contention, resulting,

\footnotetext{
${ }^{17} \mathrm{~A}$ 'one veto item' is a performance indicator related to a policy field of highest priority. Negative evaluation in this field nullifies all other achievements of a leading cadre or government unit and entails sanctions which, however, can vary between different localities.
} 
overall at least, in more responsiveness to public demands. In addition, modern technologies, such as GPS-based surveillance and online platforms for assessing public concerns on specific issues, as well as telephone-based opinion surveys and even random interviews conducted with residents in a certain locality, have been incorporated in cadre evaluation systems at all levels to ensure policy compliance of local governments. As Mei and Pearson have noted in this context,

(...) a new instrument adopted by Beijing to tackle this thorny matter ['bad discretion' and local noncompliance or defiance] is the so-called 'hold-to-account' system, or wenzezhi, which involves immediate, public and harsh sanctions against leading officials for negative policy outcomes directly resulting from the exercise of discretion over specific policy issues. It is not unprecedented for Beijing to punish leading officials for undesired outcomes. However, the hold-to-account practice became a regular management instrument after its unexpected application and success in the 2003 SARS crisis. (...) In scaring some local officials, the center aims to alter significantly the incentive structure faced by local officials. (2014, pp. 76-77; emphasis in the original). ${ }^{18}$

Taken together, all these institutional and policy reforms initiated by the central state heavily influence local cadre elites' resource base as well as the way that their economic, cultural, social and symbolic capital can be accumulated and applied. How are these changes reflected in the strategies of leading county and township cadres to safeguard their political autonomy and careers?

\section{Local Cadre Elite Habitus and Strategic Action}

\footnotetext{
${ }^{18}$ The authors also note that ' $[\mathrm{t}]$ he ability of subnational leaders to retract punishments that have been ordered by the centre in fact binds subnational officials even more closely together in policy issues such as pursuit of local economic development at all costs' (Mei \& Pearson 2014, pp. 95-96). This points at the backdrop of the central state's efforts to rein in local officials, as pressure from above strengthens their internal coherence to fight back or shirk policies.
} 
In rural China, where the gap between local cadres and the populace is huge in terms of economic, cultural, social, and symbolic capital, the former are well aware of their elite status. This becomes most clear by their internalisation of the suzhi discourse often invoked as a justification for high-handed behaviour in local politics as much as for 'social snobbery' and feelings of 'civilisational superiority' vis-à-vis the rest of the populace (Thøgersen 2003; Kipnis 2006). Obviously, local officials do not only act like an elite in the local state, they also think they are one. Nevertheless, there has been significant change in cadre behaviour and thinking caused by the repercussions of fiscal reforms, the new focus on cadre performance evaluation and the turn to 'service-oriented government' introduced to the local state in the early 2000s. Local officials must now deliver results visibly in line with upper level policies and public demands, and for that reason, they must change their attitude towards the local populace, peasants in particular. One of our respondents, the vice-director of Ganzhou City's Party School, who used to work at the township level for several years and also served as county head before being promoted to the municipality, pointed at the necessity for local cadres to adjust by explaining:

There is surely still a huge gap between cadres and the peasants: Cadres' cultural level is definitely higher than that of peasants. So when training grassroots cadres you first have to teach them that they have to present peasants with real facts. (...) Cadres who are not capable of 'rural work' will have a very hard time. If you make friends with the peasants, then it will be fine. Before the tax-for-fee reform (shuigaifei) the cadre-mass relationship was very strained. Now, I observe that this kind of tension basically does not exist anymore. Even the very contradictory task of birth control is now happening under the conditions of much better relations. That has a lot to do with cadres' communication skills. I think the cadres who do not get along well with the people are the ones with the lowest standards (zui mei you shuiping de ganbu). ${ }^{19}$

${ }^{19}$ Interview, 11 September 2010. 
Although suzhi is still a powerful concept fully internalized by local officials to distinguish themselves from other social groups, ${ }^{20}$ official rhetoric on the role of the cadre in the Chinese bureaucracy has changed in recent years and, arguably, influenced the outlook of county and township cadres. The reference to suzhi as an act of affirming a superior social status now implies foremost an obligation to respond properly to public demands and provide needed services, and to 'convince'. It is less important, even improper, to force or 'instruct' the local populace (Ahlers 2014b).

Besides good communication skills and the cultivation of harmonious cadre-mass relations, the ability to identify best practices and deliver sustainable outcomes when implementing policies are key qualifications of local officials to prove that they deserve the authority which they are entitled to. ${ }^{21}$ Younger cadres, in particular, emphasized the new need to govern by conviction, not 'instruction' or even coercion, and interestingly, many of them connected their elite status to a feeling of both proudness and social responsibility, as this leading cadre in Mizhi County's Bureau of Forestry:

I am proud to work as a county cadre because of two reasons: First, the position that I work in helps to safeguard that central government's policies are carried out smoothly on the ground. Second, I work to improve people's living conditions, as I help them to increase their income and improve the environment - that last aspect is even more important. ${ }^{22}$

\footnotetext{
${ }^{20}$ We found that the lack of suzhi is not foremost used as a simplistic negative denominator to characterise peasants or urban workers anymore but referred to by cadres as a consequence of insufficient education and economic opportunities for these social constituencies - facts which, we were told, local officials must change.

${ }^{21}$ Interestingly, our respondents in county and township government bureaus were well aware of the common critique at short-lived policy making against the background of frequently changing leading cadres (ganbu pinfan diaodong) and quite unhappy with it, too. However, promotion requires an identifiable profile of a leading cadre as an 'innovator' and nobody can sharpen this profile by just continuing what had been started by others. We nevertheless observed in a number of counties that incoming local leaders were quite careful not to rock the boat too much and rather continued where their predecessors had begun.

${ }^{22}$ Interview on 2 September 2008.
} 
The point that should be made here is simple: Local cadres believe firmly in their elite status, which is based on specific resources (or capital structure à la Bourdieu) and their positional closeness, but often agree that today 'eliteness' is linked to social responsibility, for reasons of institutional and policy change triggered by the central state, and increasingly as well by a feeling, most notably on the part of younger cadres. The changing field of local administration thus influences not only local cadre's strategies, i.e., political behaviour, but also their habitus which adapts to new normative requirements to confirm the elite status of leading local officials in this field.

So what kind of strategies do county and township cadres pursue, and how do they make use of their elite-specific capital, to ensure that policy implementation is effective? Effective policy implementation means that a policy has been implemented in accordance with central and upper level guidelines that respond to a relevant problem; this policy has been successively adjusted to local requirements and conditions; policy implementation has been checked by performance assessment and cadre evaluation procedures; public support has been mobilized through goal-defined inclusion of public demands; and tangible results 'on the ground' have been achieved. Effective policy implementation is thus ensured by the nexus of top-down performance assessment and cadre promotion, limited public mobilisation and deliberation, and the pressure of public demands that feed into the political system by telling it what kind of policies must be initiated. To put it differently, effective policy implementation is more concerned with procedural effectiveness than outcome efficiency, although outcomes must still meet public demands to the extent that a critical degree of system support is generated. In this sense, effective policy implementation is different from efficient policy implementation, the latter of which implies the existence of an external 
('objective') standard of measurement for the best way of allocating public funds and responding to public needs. ${ }^{23}$

To begin with, local officials' social capital, often denoted as locality, is an important asset to get policies on track. Although the literature abounds in reports on collusive and defiant localism ('local kingdoms') (Zhong 2003; Pieke 2004; Seckington 2007; Smith 2010), locality - meaning the disposal of social ties and networks (including lineage or clan structures) which can be strategically mobilized for achieving policy goals - is an important resource for successful local development (Xiao 2001; Tsai 2007; Zhou 2012; Kostka 2012; Li, Miao \& Lang 2011; Su 2009). It helps local officials to integrate other elites - most notably private entrepreneurs - into development plans and policy implementation processes. $^{24}$

But it is local officials' economic and structural capital that is most critical for effective policy implementation, as both capital sorts can provide privileged access to scarce resources that the private and SOE sectors urgently need: control over land, funding, information, and bureaucratic steering capacity. In fact, leading county and township cadres use their capital structure in the field of local administration systematically to guide (yindao), if not lead

\footnotetext{
${ }^{23}$ For a more comprehensive explanation of the concept and its application to local policy implementation in China see Ahlers and Schubert (2015).

${ }^{24}$ See also Ahlers, Heberer and Schubert (2016). Moreover, as Heberer and Schubert (2012) have pointed out, locality does also refer to an intrinsic motivation of leading officials to live up to certain value orientations stemming from a personal attachment to the place they are working in (which may be close to their home village or township), their socialisation, or past (traumatic) experiences like the Cultural Revolution or privatisation in the 1990s. Many of our interviewees spontaneously displayed intrinsically grounded 'locality' when asked about their work. For instance, a leading cadre in Mizhi County's Bureau of Rural Works stated: 'I am proud to work as a county cadre, because I was born and raised in the countryside and most of my friends still live here. I am very satisfied with my work and position. I receive a lot of support from the townships, villages and the population and work is therefore going very well (Interview, 1 September 2008).
} 
(lingdao), other social constituencies and urge them into compliance (Heberer \& Schubert 2014).

More precisely, they skillfully and creatively adjust policy guidelines from above to come up with development blueprints propagating the 'marketable' features of their respective localities in order to compete successfully for project funding allocated by superior administrative levels - for example, a certain cash crop, a local 'best practice', historical sites, local folk culture or cuisine, an 'innovative' or 'entrepreneurial' spirit, and sometimes just outright 'backwardness' turned into 'ecological record'. The master plan often is to set up a local 'model' that is fit for translocal, even national emulation. Only visible and continuous success in making good on the promises of these development plans ensures cadres' promotion while pure image-building and continuous implementation failure entails enormous pressure and negative repercussions on career advancement (Ahlers 2014b; Ahlers \& Schubert 2013).

To get their projects on track, leading county and township cadres streamline administrative procedures and set up informal coordination mechanisms across government bureaus to enhance implementation quality control (Schubert \& Ahlers 2009, 2012a). They strategically allocate scarce money, buffered by upper level subsidies and earmarked funds, to townships and villages with a proven record of efficiency and political reliability. They are keeping high pressure on their bureaucracies at each administrative level - county, township and village by strict matching fund requirements (peitao) and step-by-step funding subjected to periodic project evaluation. ${ }^{25}$ Hence, township and village governments are kept on tight budgets in the process of policy implementation to avoid the waste of money and for making all

\footnotetext{
${ }^{25}$ Counties are subjected to the same practice by municipal and provincial governments.
} 
government levels interested stakeholders in the overall success of a project. Recent research suggests that this logic of allocating and controlling funds may not completely rule out the diversion of public money nor does it prevent corrupt personal enrichment of cadres (Gong \& Wu 2012; Liu et al. 2009). However, given the overall institutional environment in the local state today, the steering capacity and authority of leading county and township cadres resulting from their elite-specific (economic, social, structural) capital, and their habitusdriven motivation - even a self-perceived mission - to act as a local elite, has made policy implementation more transparent, responsible and responsive to public demands (Ahlers 2014b; Heberer \& Schubert 2014).

Strategic action does also target overall cadre and performance evaluation to which leading county and township cadres are subjected and which they impose on the bureaucracies they manage ${ }^{26}$ In order to enforce compliance of their subordinates, these elites use the evaluation mechanism as a 'self-priming pump' that pushes all local cadres in the same direction and avoids extreme development disparities across a county (Landry 2008). Simultaneously, the same officials may collude to shirk upper level pressure by uniting all sub-level governments in an effort to deceive inspection teams from above or to manipulate official reports and figures in evaluation forms (Zhou 2012). ${ }^{27}$ Although cadre and performance evaluation is foremost an instrument of intra-party control, the incorporation of 'social stability' (shehui wending) as an indicator attached to different performance categories increasingly factors in public opinion, usually by way of limited surveys among the rural populace or their

\footnotetext{
${ }^{26}$ The evaluation system is therefore two-dimensional: as a constraining institution, it exercises topdown control on the local elite, but at the same time local elites use the system and adapt its tools in order to streamline the policy process throughout their jurisdictions.

${ }^{27}$ As our research has shown, the weighting of local evaluation indicators is regularly adjusted to local policy prioritisation, and sometimes new indicators or performance categories are added by specifying or rearranging upper level guidelines. Leading county officials engage in sophisticated bargaining with their superiors on these modifications (Ahlers 2014b; Ahlers \& Schubert 2015; Schubert \& Ahlers 2012a).
} 
representatives in Village Committees, Village Representative Assemblies or Local Peoples' Congresses, and Political Consultative Conferences. This is less understood as a measure to strengthen citizen participation in local policy implementation per se than as a useful means to reinforce the pressure on the local bureaucracy to deliver effectively.

But how do local elites in contemporary China manage their relations with the overall population they govern? As mentioned, local governments are now largely relieved of strained cadre-peasant relations caused by the highly contested exaction of taxes and fees. Moreover, expansion of public participation has gained more importance in local governance since the nation-wide implementation of direct village elections in 1998 (Mertha 2009; Thøgersen 2009, 2011; He \& Warren 2011; Schubert \& Ahlers 2012b). And the relevance and influence of Local People's Congresses and Political Consultative Congresses has become more meaningful in local politics over time (Yan 2011; Manion 2014). This all suggests that public demands and responses are increasingly taken into account when designing and carrying out local policy implementation, with the overall objective to ensure 'social stability' (shehui wending). Furthermore, a rising number of policy initiatives, such as the 'service-oriented government' campaign or the recently revised 'Environmental Protection Law' (huanjing baohu fa), now explicitly call for more citizen engagement in local administration. Though public participation constitutes a burden for local political elites, as it renders policy making more complex and riskier, the 'participation imperative' in most of the places we observed was met affirmatively, albeit with much tactical creativity. In Dingnan county of southern Jiangxi province, for instance, county and township leaders encouraged villager small groups (cunmin xiaozu) to act as mediators for facilitating community development initiatives. They also initiated to set up so-called villager administrative councils (cunmin lishi hui) to smoothen and manage the implementation of relocation 
projects. In both cases, local leaders aimed at mobilizing social networks within villages to 'do work' on recalcitrant villagers, hence bypassing the formal institutions of villager selfgovernment, i.e. villager committees (cunmin weiyuanhui), villager representative assemblies (cunmin daibiao dahui) and village party cells (dangzhibu). While these specific institutional innovations must rather be understood as mechanisms to spur goal-oriented public mobilisation than to deepen democratic participation, we found that they were often effective in negotiating compromises between local governments, peasants and entrepreneurs, eventually paving the way for successful policy implementation while maintaining 'social stability’ (Ahlers \& Schubert 2015; Ahlers 2014a, 2014b; Heberer \& Schubert 2014; Schubert \& Ahlers 2013a). Wu Wei et al., for their part, come to the conclusion that the implementation of 'service oriented government' is relatively successful as the local population of different Chinese cities has become more satisfied with governmental services and policy implementation in recent years. Interestingly enough, their study also showed that the level of satisfaction did not significantly correlate with the degree of socio-economic development, but rather with the citizens' assessment of their chances for participation in the design and implementation of measures connected to public goods provision. This, so the authors argue, explains relatively high degrees of acceptance of local elites even in less developed regions (Wu et al. 2013, pp. 1-26).

As has been highlighted by much earlier research already, China's local cadre elites dispose over significant degrees of autonomy and resources to implement upper level policy guidelines. However, in contrast to the first three decades of 'reform and opening', the institutional environment of leading local cadres has changed a lot. Overall, the provision of public goods in the local state has improved considerably since the early 2000s (for the countryside see e.g. Long et al. 2011; Unger 2012), highlighting the fact that local elites are 
increasingly responding to public needs and demands while citizen participation in and control of the policy process itself has remained restricted.

Most observers agree that the (re-)centralisation efforts initiated under the aegis of Xi Jinping since 2013 seriously curtail local governments' political autonomy and level of activity. Apparently, these attempts at stronger top-down steering are still being intensified, as the central leadership is not yet satisfied with the speed and scope of the local implementation of its 'comprehensive reform' program. In fact, we can observe a decrease in locally-initiated policy experimentation, pressure and anxiety caused by the latest sweeping anti-corruption campaign and disciplinary measures, a reform of the intergovernmental transfer and policy funding system, and an increase in time spent on ideological training. The concrete effects of these ongoing reconfigurations on local governments' policy implementation capacities will have to be scrutinized by further empirical research. For the time being, however, we hold that the mechanisms of central-local relations we have described in this chapter remain valid and that the recent recalibrations will not profoundly alter the set-up that caters to the center's long grown, delicate reliance on local cadre elites' agency for adaptive and effective policy implementation.

\section{Conclusion}

This chapter conceptualized leading county and township cadres as local political elites. It described how these local officials, bestowed with similar constellations of Bourdieuan capital and a distinct habitus that generates group coherence, fill this role by constantly learning how to adapt to political challenges to their autonomy and power by policy shifts and institutional reforms (as in public finance and cadre performance evaluation). Local 
officials today are increasingly required to foster more balanced economic growth and to strengthen public goods provision - most notably, infrastructural development, education, social security, and, in general: services. Arguably, they succeed in doing so, thus turning structural constraints into new (social, economic, structural) capital which strengthens their relative power position in the field of local administration. For the time being, county and township cadres have not (yet) been truly challenged by other elites and have so far successfully coopted (private entrepreneurs, SOE mangers) or controlled (social activists) these potentially competing forces.

Contrary to many scholars' assessment of the central-local state nexus, we argue that the current political system produces a reconciliation of central state policy objectives with local state claims to bureaucratic decentralisation and the delegation of power. Without changing the operational logic of the administrative system, the political leadership increasingly builds upon local elites' discretion while maintaining meaningful institutional control. This governance approach entails, at least in many parts of China, policy implementation that answers to both higher level instructions and local demands. Defiance is still possible and policy implementation is not always effective. However, local political elite's desire for autonomy and career advancement is now - more than ever - critically linked to positive outcomes in policy implementation. Local political elites can hardly legitimise themselves today if they do not deliver to the local populace - though not all demands of the latter must, or can, be satisfied. Local cadre elites at county and township level therefore are important forces to keep the Chinese political system going. As during imperial times, the center has to make sure that the degree of institutional control imposed on them and the extent of autonomy given to them are well calibrated, so that political malfunction can be avoided and 'dynastic change' postponed. 


\section{References}

Ahlers, AL 2015, 'Weaving China's Dream On the Ground: Local Government Approaches to “New-Typed” Rural Urbanization', Journal of Chinese Political Science, vol. 20, no. 2, pp. $121-42$.

Ahlers, AL 2014a, 'Lokales Regieren und Administrative Interessenvermittlung in China (Local Governance and Administrative Interest Mediation in China)', in H Heinelt (ed.), Modernes Regieren in China (Modern governance in China), Nomos, Baden-Baden.

Ahlers, AL 2014b, Rural Policy Implementation in Contemporary China: New Socialist Countryside, Routledge, London.

Ahlers, AL, Heberer, T \& Schubert, G 2016, 'Whither Local Governance in Contemporary China? Reconfiguration for More Effective Policy Implementation', Journal of Chinese Governance, vol. 1, no. 1, pp. 55-77.

Ahlers, AL \& Schubert, G 2015, 'Effective Policy Implementation in China's Local State', Modern China, vol. 41, no. 4, pp. 372-405.

Ahlers, AL \& Schubert, G 2013, 'Strategic Modelling: "Building of a New Socialist Countryside" in Three Chinese Counties', The China Quarterly, vol. 216, pp. 831-49. 
Ahlers, AL \& Schubert, G 2009, “"Building a New Socialist Countryside” - Only a Political Slogan?', Journal of Current Chinese Affairs, vol. 38, no. 4, pp. 35-62.

Ang, YY (2016), 'Beyond Weber: Conceptualizing and Alternative Ideal Type of Bureacracy in Developing Contexts', Regulation \& Governance, doi: 10.1111/rego.12123.

Barbieri-Low, A 2011, 'Model Legal and Administrative Forms from the Qin, Han, and Tang and Their Role in the Facilitation of Bureaucracy and Literacy', Oriens Extremus, vol. 50, pp. 125-156.

Bernstein, TP \& Lü, X 2003, Taxation Without Representation in Contemporary Rural China, Cambridge University Press, Cambridge.

Bernstein, TP \& Lü, X 2000, 'Taxation without Representation: Peasants, the Central and the Local States in Reform China', The China Quarterly, vol. 163, pp. 742-63.

Burns, JP 2007, 'Civil Service Reform in China', OECD Journal on Budgeting, vol. 7, no. 1, pp. 1-25.

Burns, JP 2006, 'The CCP's Nomenklatura System', in KE Brødsgaard \& Y Zheng (eds.), The Chinese Communist Party in Reform, Routledge, London.

Burns, JP \& Wang, X 2010, 'Civil Service Reform in China: Impacts of Civil Servants Behaviour', The China Quarterly, vol. 201, pp. 58-78. 
Cai, Y 2004, 'Irresponsible State: Local Cadres and Image-Building in China', Journal of Communist Studies and Transition Politics, vol. 20, no. 4, pp. 20-41.

CCP Central Committee 2013, Zhonggong zhongyang guanyu quanmian shenhua gaige ruogan zhongda wenti de jueding (The CCP central committee's decision on major issues concerning comprehensively deepening reforms), 15 November, viewed 20 December 2013, http://news.xinhuanet.com/politics/2013-11/15/c_118164235.htm

CCP Central Committee 2011, Zhongyang zhengwu gongkai 'yijian' zhuli fuuxing zhengfu jianshe ('Suggestions' on the transparency of central government's administrative affairs support the construction of a service-oriented government), 3 August, viewed 15 August 2014, http://cpc.people.com.cn/GB/64093/64103/15323011.html

CCP Central Committee 2010, Zhonggong zhongyang bangongting yinfa 'guanyu tuijin xuexixing dang zuzhi jianshe de yijian' (CCP Central Committee issues 'suggestions on the promotion of building a learning Party Organisation'), 8 February, viewed 15 August 2014, http://www.gov.cn/jrzg/2010-02/08/content_1531011.htm

CCP News 2007, Ruhe lijie jianshe fuwuxing zhengfu (How to understand the construction of a service-oriented government), 2 October, viewed 15 August 2014, http://theory.people.com.cn/GB/49150/49152/6339521.html

CCP Organisation Department 1998, Dangzheng lingdao ganbu kaohe gongzuo zhanhang guiding (Interim provisions for evaluation of party and government leading cadres), viewed 15 August 2014, http://cpc.people.com.cn/BIG5/64162/71380/71382/71480/4853966.html 
Chen, A 2014, 'How Has the Abolition of Agricultural Taxes Transformed Village Governance in China? Evidence from Agricultural Regions', The China Quarterly, vol. 219, pp. 715-35.

Chü, Tung-tsu 1962, Local Government in China under the Ch'ing, Stanford University Press, Stanford.

Cui, S 2009, Zhongguo difang zhengfu jixiao pinggu fangfa yu yingyong yanjiu (A research of assessment methodology and its application on the performances of the local Governments in China), Zhongguo tongji chubanshe, Beijing.

Eaton, S \& Kostka, G 2014, 'Authoritarian Environmentalism Undermined? Local Leaders' Time Horizons and Environmental Policy Implementation in China', The China Quarterly, vol. 218, pp. 359-80.

Eisenstadt, SN 1958, 'Bureaucracy and Bureaucratisation', Current Sociology, vol. 7, pp. 99124.

Göbel, C 2012, 'Government Propaganda and the Organisation of Rural China', in A Bislev \& S Thøgersen (eds.), Organizing Rural China - Rural China Organizing, Lexington Books, Lanham.

Göbel, C 2011, 'Paving the Road to a Socialist New Countryside: China's Rural Tax and Fee Reform', in B Alpermann (ed.), Politics and Markets in Rural China, Routledge, London. 
Göbel, C 2010, The Politics of Rural Reform in China, Routledge, London-New York.

Göbel, C 2008a, 'Measuring and Explaining the Distributive Effects of Rural Tax and Fee Reform in Anhui Province', China Perspectives, vol. 2, pp. 58-74.

Göbel, C 2008b, 'The Peasant's Rescue from the Cadre? An Institutional Analysis of China's Rural Tax and Fee Reform', in T Heberer \& G Schubert (eds.), Regime Legitimacy in Contemporary China: Institutional Change and Stability, Routledge, London.

Gong, T \& Wu, AM 2012, 'Central Mandates in Flux: Local Noncompliance in China', Publius: The Journal on Federalism, vol. 42, no. 2, pp. 313-33.

Guo, B 2010, China's Quest for Political Legitimacy: The New Equity-Enhancing Politics, Lexington Books, Lanham.

Guo, G 2008, 'Vertical Imbalance and Local Fiscal Discipline in China', Journal of East Asian Studies, vol. 8, pp. 61-88.

He, B \& Warren, ME 2011, ‘Authoritarian Deliberation: The Deliberative Turn in Chinese Political Development', Perspectives on Politics, vol. 9, no. 2, pp. 269-89.

Heberer, T \& Schubert, G 2014, 'Developmentalism and Strategic Agency in China’s Local State: Preliminary Findings from Recent Fieldwork', paper presented at the Conference on 
Governance, Adaptability and System Stability under Contemporary One-Party Rule, Nanchang, 27-29 March.

Heberer, T \& Schubert, G 2012, 'County and Township Cadres as a Strategic Group. A New Approach to Political Agency in China's Local State', Journal of Chinese Political Science, vol. 17 , no. 3, pp. 221-49.

Heberer, T \& Senz, A 2011, 'Streamlining Local Behaviour Through Communication, Incentives and Control: A Case Study of Local Environmental Policies in China', Journal of Current Chinese Affairs, vol. 3, pp. 77-112.

Heberer, T \& Trappel, R 2013, ‘Evaluation Processes, Local Cadres’ Behaviour and Local Development Processes', Journal of Contemporary China, vol. 22, no. 84, pp. 1048-66.

Heilmann, S 2011, 'Policy-Making through Experimentation: The Formation of a Distinctive Policy Process', in S Heilmann \& EJ Perry (eds.), Mao's Invisible Hand: The Political Foundations of Adaptive Governance in China, Harvard University Press, Cambridge/Mass.

Heilmann, S 2009, 'Maximum Tinkering Under Uncertainty: Unorthodox Lessons From China', Modern China, vol. 35, no. 4, pp. 450-62.

Heilmann, S 2008, 'Policy Experimentation in China's Economic Rise', Studies in Comparative International Development, vol. 43, no. 1, pp. 1-26. 
Hillman, B 2010, 'Factions and Spoils: Examining Political Behavior within the Local State in China', The China Journal, vol. 64, pp. 1-18.

Houlgate, S \& Baur, M (eds.) 2011, A Companion to Hegel, Wiley-Blackwell, Oxford.

Huang, B \& Chen, K 2012, 'Are Intergovernmental Transfers in China Equalizing?', China Economic Review, vol. 23, no. 3, pp. 534-51.

Jing, Y 2010, 'History and Context of Public Administration in Mainland China', in EM Berman, MJ Moon \& H Choi (eds.), Public Administration in East Asia. Mainland China, Japan, South Korea, and Taiwan, CRC Press-Taylor and Francis Group, London.

Kennedy, JJ 2007, 'From the Tax-for-Fee Reform to the Abolition of Agricultural Taxes: The Impact on Township Governments in North-west China', The China Quarterly, vol. 189, pp. 43-59.

Kim, SH 2012, 'Max Weber', in EN Zalta (ed.), The Stanford Encyclopedia of Philosophy, viewed 1 September 2014, http://plato.stanford.edu/archives/fall2012/entries/weber/

Kipnis, AB 2006, 'Suzhi: A Keyword Approach', The China Quarterly, vol. 186, pp. 295 313.

Koselleck, R 1967, Preußen zwischen Reform und Revolution (Prussia between reform and revolution), Ernst Klett Verlag, Stuttgart. 
Kostka, G 2012, 'Mobility and Agency: Private Sector Development in Rural Central China', The China Journal, vol. 67, no. 1, pp. 47-65.

Landry, P 2008, Decentralized Authoritarianism in China: The Communist Party's Control of Local Elites in the Post-Mao Era, Cambridge University Press, Cambridge.

Li, C \& Bachmann, D 1989, 'Localism, Elitism, and Immobilism: Elite Formation and Social Change in Post-Mao China', World Politics, vol. 42, no. 1, pp. 64-94.

Li, LC 2007, 'Working for the Peasants? Strategic Interactions and Unintended Consequences in the Chinese Rural Tax Reform', The China Journal, vol. 57, pp. 89-106.

Li, Y, Miao, B \& Lang, G 2011, 'The Local Environmental State in China: A Study of County-Level Cities in Suzhou', The China Quarterly, vol. 205, pp. 115-32.

Liu, M \& Tao, R 2007, 'Local Governance, Policy Mandates and Fiscal Reform in China', in V Shue \& C Wong (eds.), Paying for Progress in China: Public Finance, Human Welfare and Changing Patterns of Inequality, Routledge, London.

Liu, M, Wang, J, Tao, R \& Murphy, R 2009, ‘The Political Economy of Earmarked Transfers in a State-Designated Poor County in Western China: Central Policies and Local Responses', The China Quarterly, vol. 200, pp. 973-94.

Liu, Y 2012, 'From Predator to Debtor: The Soft Budget Constraint and Semi-Planned Administration in Rural China', Modern China, vol. 38, no. 3, pp. 308-45. 
Lollar, XL \& Hamilton, AW 2010, 'Patronage or Prebendalism? The 'Mishu/Shouzhang' Relationship and Corruption in Chinese Politics', China Review, vol. 10, no. 1, pp. 157-82.

Long, H, Zou, J, Pykett, J \& Li, Y 2011, 'Analysis of Rural Transformation Development in China Since the Turn of the New Millennium', Applied Geography, vol. 31, no. 3, pp. 1094105.

Lou, J \& Wang, S (eds.) 2008, Public Finance in China: Reform and Growth for a Harmonious Society, The World Bank, Washington.

Manion, M 2014, 'Authoritarian Parochialism: Local Congressional Representation in China', The China Quarterly, vol. 218, pp. 311-38.

Mei, C \& Pearson, MM 2014, 'Killing a Chicken to Scare the Monkeys? Deterrence Failure and Local Defiance in China', The China Journal, vol. 72, no. 2, pp. 75-97.

Mertha, AC 2009, “"Fragmented Authoritarianism 2.0”: Political Pluralisation in the Chinese Policy Process', The China Quarterly, vol. 200, pp. 995-1012.

Mulgan, R 2002, 'Public Accountability of Provider Agencies: The Case of the Australian “Centrelink", International Journal of Administrative Sciences, vol. 68, no. 1, pp. 45-59.

O’Brien, KJ. \& Li, L 1999, 'Selective Policy Implementation in Rural China', Comparative Politics, vol. 31, no. 2, pp. 167-86. 
Ongaro, E 2004, 'Process Management in the Public Sector: The Experience of One-Stop Shops in Italy', International Journal of Public Sector Management, vol. 17, no. 1, pp. 81107.

Pieke, F 2004, Transnational Chinese: Fujianese Migrants in Europe, Stanford University Press, Stanford (first author with Pál Nyíri, Mette Thunø and Antonella Ceccagno, 2004).

Rothman, S 2011, 'Political Elites: Recruitment and Careers', in NJ Smelser \& PB Baltes (eds.), International Encyclopedia of the Social \& Behavioral Sciences, Pergamon, Oxford.

Sato, H 2008, 'Public Goods Provision and Rural Governance in China', China: An International Journal, vol. 6, no. 2, pp. 281-98.

Schoppa, RK 2010, 'The Political Creativity of Late Imperial China', in B Womack (ed.), China's Rise in Historical Perspective, Rowman \& Littlefield, Lanham.

Schubert, G \& Ahlers, AL 2012a, 'County and Township Cadres as a Strategic Group: "Building a New Socialist Countryside" in Three Provinces', The China Journal, vol. 67, pp. 67-86.

Schubert, G \& Ahlers, AL 2012b, Participation and Empowerment at the Grassroots Chinese Village Elections in Perspective. Lexington Books, Lanham. 
Schubert, G \& Ahlers, AL 2011, “"Constructing a New Socialist Countryside” and Beyond: An Analytical Framework for Studying Policy Implementation and Political Stability in Contemporary China', Journal of Chinese Political Science, vol. 16, no. 1, pp. 19-46.

Seckington, I 2007, 'County Leadership in China: A Baseline Survey', China: An International Journal, vol. 5, no. 2, pp. 204-27.

Shah, A \& Shen, C 2008, 'Fine-Tuning the Intergovernmental Transfer System to Create a Harmonious Society and a Level Playing Field for Regional Development', in J Lou \& S Wang (eds.), Public Finance in China: Reform and Growth for a Harmonious Society, The World Bank, Washington.

Smith, G 2013, 'Measurement, Promotions and Patterns of Behavior in Chinese Local Government', The Journal of Peasant Studies, vol. 40, no. 6, pp. 1027-50.

Smith, G 2010, 'The Hollow State: Rural Governance in China', The China Quarterly, vol. 203, pp. 601-18.

Smith, G 2009, 'Political Machinations in a Rural County', The China Journal, vol. 62, pp. $29-59$.

Stepan, M \& Müller, A 2012, 'Welfare Governance in China? A Conceptual Discussion of Governing Social Policies and the Applicability of the Concept to Contemporary China', Journal of Cambridge Studies, vol. 7, no. 4, pp. 54-72. 
Su, M 2009, China's Rural Development Policy: Exploring the "New Socialist Countryside", FirstForumPress, Boulder CO.

Tao, R, Liu, M, Su, F \& Lu, X 2011, 'Grain Procurement, Tax Instrument, and Peasant Burdens during China's Rural Transition', Journal of Contemporary China, vol. 20, no. 71, pp. 659-77.

Thøgersen, S 2011, 'Building a New Socialist Countryside: Model Villages in Hubei’, in Björn Alpermann (ed.), Politics and Markets in Rural China, Routledge, London.

Thøgersen, S 2009, 'Revisiting a Dramatic Triangle: The State, Villagers and Social Activists in Chinese Rural Reconstruction Projects', Journal of Current Chinese Affairs, vol. 38, no. 4, pp. 9-33.

Thøgersen, S 2003, 'Parasites of Civilisers: The Legitimacy of the Chinese Communist Party in Rural Areas', China: An International Journal, vol. 1, no. 2, pp. 200-23.

Tsai, LL 2007, Accountability Without Democracy: Solidarity Groups and Public Goods Provision in Rural China, Cambridge University Press, Cambridge.

Tsui, K \& Wang, Y 2004, 'Between Separate Stoves and A Single Menu: Fiscal Decentralisation in China', The China Quarterly, vol. 177, pp. 71-90. 
Unger, J 2012, 'Continuity and Change in Rural China's Organisation', in A Bislev \& S Thøgersen (eds.), Organizing Rural China - Rural China Organizing, Lexington Books, Lanham.

Wang, H 2008, 'Rethinking the Rise of Modern Chinese Thought', Modern China, vol. 34 no. 1, pp. 114-40.

Wang, Z \& Pavlicevic, D 2014, 'Transitional Meritocracy: Institutions and Practices of Personnel Management in Contemporary China's Party State', in KE Brødsgaard (ed.), Globalisation and Public Sector Reform in China, Routledge, London.

Wedeman, A 2003, From Mao to Market: Rent Seeking, Local Protectionism and Marketisation in China, Cambridge University Press, Cambridge.

Wei, L 2006, 'Guowuyuan yanjiushi zhuren Wei Liqun: dali jianshe fuwuxing zhengfu (State Council Research Office director Wei Liqun: Strong efforts to build a service-oriented government)', Qiushi, 1 November, viewed 15 August 2014, www.gov.cn/zwhd/2006$\underline{11 / 01 / \text { content_429890.htm }}$

Whiting, SH 2004, 'The Cadre Evaluation System at the Grassroots: The Paradox of Party Rule', in BJ Naughton \& D Yang (eds.), Holding China Together: Diversity and National Integration in the Post-Deng-Era, Cambridge: Cambridge University Press.

Wiggan, J 2007, 'Reforming the United Kingdom's Public Employment and Social Security Agencies', International Review of Administrative Science, vol. 73, no. 3, pp. 409-24. 
Wong, C \& Bird, RM 2008, 'China's Fiscal System: A Work in Progress', in L Brandt \& TG Rawski (eds.), China's Great Economic Transformation, Cambridge University Press, Cambridge.

Wu, W, Yu, W, Lin, T, Wang, J \& Tam, W 2013, 'Evaluating Public Service Performance in Urban China: Findings from the 2011 Lien Chinese Cities Service-Oriented Government Project', in W Wu (ed.), Building Service-Oriented Government: Lessons, Challenges and Prospects, World Scientific, Singapore.

Xiao, T 2001, Cunzhi zhong de zongzu: Dui jiuge cun de diaocha yu yanjiu (Clans in village governance: Survey and research on nine villages), Shanghai Shudian, Shanghai.

Xinhuanet 2014, 'China's Urbanisation Level to Reach 60 Per Cent by 2020', 16 March, viewed 21. March 2014, http://news.xinhuanet.com/english/china/2014-

$\underline{03 / 16 / \text { c } 133190605 . h t m}$

Xinhua Press (n.s.) 2006, Jianshe shehui zhuyi xinnongcun. Xuexi duben (Study book for the construction of a new socialist countryside), Xinhua chubanshe, Beijing.

Yan, X 2011, 'Regime Inclusion and the Resilience of Authoritarianism: The Local People's Political Consultative Conference in Post-Mao Chinese Politics', The China Journal, vol. 66, pp. 53-75. 
Ye, X 2009, 'China's Urban-Rural Integration Policies', Journal of Current Chinese Affairs, vol. 38 , no. 4 , pp. $117-43$.

Yep, R 2008, 'Enhancing the Redistributive Capacity of the Chinese State? Impact of Fiscal Reforms on County Finance', Pacific Review, vol. 21, no. 2, pp. 231-55.

Yu, K 2016, 'Learning, Training, and Governing: The CCP's Cadre Education since the Reform', Journal of Chinese Governance, vol. 1, no. 1, pp. 41-54.

Zhong, Y 2003, Local Government and Politics in China: Challenges from Below, M. E. Sharpe, Armonk.

Zhou, X 2012, 'The Road to Collective Debt in Rural China: Bureaucracies, Social Institutions, and Public Goods Provision', Modern China, vol. 38, no. 3, pp. 271-307.

Zhou, X 2010, 'The Institutional Logic of Collusion among Local Governments in China', Modern China, vol. 36, no. 1, pp. 47-78.

Zhou, X, Ai, Y \& Lian, H 2012, 'The Limit of Bureaucratic Power in Organisations: The Case of the Chinese Bureaucracy', Research in the Sociology of Organisations, vol. 34, no. 34, pp. 81-111.

Zhuang, G 2007, Lingdao ganbu zhengji pingjia de lilun yu shijian (Theory and practice of leading cadre evaluation), Zhongguo Jingji Chubanshe, Beijing. 